\title{
Morphophysiological analysis and expression of proline genes in rice (Oryza sativa L. cv. BRS AG) subjected to in vitro salt stress
}

\author{
Tatiana Rossatto ${ }^{1}$, Mara Andrade C. Maia ${ }^{2}$, Marcelo N. Amaral ${ }^{1}$, Priscila A. Auler ${ }^{1}$, Rafael Woloski ${ }^{2}$, Ariano \\ M. M. Júnior ${ }^{3}$, Eugenia J. B. Braga ${ }^{1}$, Luciana B. Dode ${ }^{2}$, Luciano S. Pinto ${ }^{2^{*}}$
}

${ }^{1}$ Instituto de Biologia, Departamento de Botânica, Universidade Federal de Pelotas, Campus Universitário, S/N 96160-000, Capão do Leão, RS - Brasil

${ }^{2}$ Centro de Desenvolvimento Tecnológico, Núcleo de Biotecnologia, Laboratório de Bioinformática e Proteômica (BioPro_Lab), Universidade Federal de Pelotas, Campus Universitário, S/N - 96160-000, Capão do Leão, RS - Brasil ${ }^{3}$ Embrapa Clima Temperado, S/N - 96001-970, Pelotas, RS - Brasil

\section{*Corresponding author: Is_pinto@hotmail.com (L. S. Pinto)}

\begin{abstract}
About $20 \%$ of the cultivated land and almost half of the irrigated lands of the planet are affected by the salinization of the soil and the water. Rice cultivar BRS AG is the first grown for other purposes than human consumption and can be used in the production of ethanol and animal feed. The objective of this study was to evaluate the germination, morphological characteristics, proline accumulation, and the expression of the genes involved in the metabolism of proline in rice plants, cV. BRS AG, cultured in vitro under salt stress. The plants were cultivated in a culture MS medium with six different $\mathrm{NaCl}$ concentrations $(0,32,68,102,136,170$ $\mathrm{mM}$ ). The germination was evaluated at days 7 and 14 , and morphological characteristics were analyzed only at day 21 . For proline quantification and expression of the genes required for its metabolism (P5CS1, P5CS2, P5CR, OAT, P5CDH and PDH), two concentrations (136 mM and $0 \mathrm{mM}$ ) of $\mathrm{NaCl}$ were used, and the samples were collected at days $5,10,15$, and 20 . The results indicate that the growth of rice cv. BRS is completely impaired at $170 \mathrm{mM} \mathrm{NaCl}$, and at $136 \mathrm{mM} \mathrm{NaCl}$. Regarding proline content, in stressed plants, it was higher $\left(1.24 \mathrm{mM} \mathrm{g}^{-1} \mathrm{MF}\right)$ than in the control plants, and was directly related to a high expression observed for the P5CS2 (QR=5.50) and OAT (QR=5.44) genes at 20 days of stress, which explains the high proline concentration at this period. According to the results, rice cultivar BRS AG, is considered tolerant to salt stress.
\end{abstract}

Keywords: Genes; Germination; In vitro culture; Oryza sativa L.; Salinity.

Abbreviations: RQ_relative quantification; ROS_reactive oxygen species; GSA_ glutamate semialdehyde; P5CS_ Pyrroline-5carboxylate synthetase; $\mathrm{P} 5 \mathrm{C}_{-}$pyrroline-5-carboxylate; $\mathrm{P} 5 \mathrm{CR}$ _ pyrroline-5-carboxylate reductase; OAT_ornithine-deltaaminotransferase; $\mathrm{PDH}$ _proline dehydrogenase; $\mathrm{P} 5 \mathrm{CDH}$ _P5C dehydrogenase; FM_ fresh mass; MS_Murashige and Skoog; UBQ10_Ubiquitin 10; APDM_Aerial Part Dry Mass; RDM_Root dry mass.

\section{Introduction}

Rice is one of the crops with the most social and economic impact in Brazil (Sosbai, 2014), and the state of Rio Grande do Sul (RS) is the largest producer in Brazil, representing over $68.8 \%$ of the overall rice produced in the country (Conab, 2015).

However, recently, the rice production found the possibility of getting new markets. An example of this is the development of cultivar BRS AG, the first irrigated rice cultivar, which can be used as a raw material in the production of ethanol and feedstock, as it does not meet the standards of rice suitable for human consumption in Brazil (Magalhães Júnior et al., 2017).This cultivar has a biological cycle of about 126 days (from emerging to maturation), big grains with high starch content, no beards, and a high productive capacity. The average weight of a thousand seeds is 52 grams, while the vast majority of the irrigated rice cultivars have an average weight of 25 grams. The development of this cultivar had the goal of supplying raw material for feedstock and expand ethanol production in the state of Rio Grande do Sul, since the production of ethanol from sugar cane as it occurs in other regions of contry is limited in this region due to the climatic conditions (Magalhães Júnior et al., 2017). However, there are no studies on the physiology of this new cultivar, mainly in stress conditions.

Rice is characterized as being more sensitive to salt in the seedling and reproductive phases than during vegetative growth and tillering. When the salinity level is above the tolerance of the plant, it causes a decrease in tillering, chlorosis, leaf death, and plant height loss, and also results in spikelet sterility and non-productive tillers (Carmona, 2011).

Osmotic stress and ion toxicity are the effects promoted by high levels of salinity. Osmotic stress is the result of a 
reduction in the rate of water absorption by the plants, while ion toxicity is caused by the excess of ions absorbed in the transpiration stream. In these conditions, reduction or delay in the germination process (Ozhan and Hajibabaei, 2013; Soares et al., 2015), growth reduction, especially of the shoots (Munns and Tester, 2008), nutritional imbalance (Asci, 2013), senescence and apoptosis (Silveira et al., 2010) can occur. One of the secondary stresses due to salinity is the oxidative stress, resulting from uncontrolled metabolism, producing reactive oxygen species (ROS). ROS are also produced in plant cells under normal metabolic conditions; however, in excess they cause severe cell damage.

In response to the environmental disturbances, plants build up large amounts of compatible solutes, such as proline, glycine betaine, glycerol, mannitol, sorbitol, among others, that protect the cells against damages caused by the stress. Proline is widely present in higher plants, and can be accumulated in considerably high quantities in response to salt stress and hydric restriction (Kavi Kishor et al., 2005). It is highly soluble in water, which allows it to be accumulated in high concentrations in the cytosol of plant cells with no harm to the structures (Silveira et al., 2010). The main function of proline is osmoregulation that protects the cells from osmotic stress, besides other functions (Ben Rejeb et al., 2014). Proline accumulation in stress conditions can help in the maintenance of respiratory and photosynthetic processes (Kavi Kishor et al., 2005).

In plants, proline can be synthesized through the glutamate and ornithine pathways. Glutamate is reduced to glutamate semialdehyde (GSA) through the action of the pyrroline-5-carboxylate synthetase enzyme (P5CS), and spontaneously converted to pyrroline-5-carboxylate (P5C). $\mathrm{P} 5 \mathrm{C}$ is reduced to proline by the pyrroline-5-carboxylate reductase enzyme (P5CR) (Ben Rejeb et al., 2014). Another alternative for the proline synthesis is the ornithine pathway, which is transaminated to $\mathrm{P} 5 \mathrm{C}$ by the ornithinedelta-aminotransferase enzyme (OAT), and then converted to proline (Verbruggen and Hermans, 2008). The catabolism occurs in the mytochondria, where the enzyme proline dehydrogenase $(\mathrm{PDH})$ converts proline to $\mathrm{P5C}$ which, through the $\mathrm{P} 5 \mathrm{C}$ dehydrogenase enzyme $(\mathrm{P} 5 \mathrm{CDH})$, produces glutamate (Ben Rejeb et al., 2014).

Usually, the pyrroline-5-carboxilate synthetase enzyme (P5CS) is coded by two genes (P5CS1 and 2), while the pyrroline-5-carboxilate redutase (P5CR) is coded by only one gene (Armengaud et al., 2004). Likewise, the proline dehydrogenase enzyme (PDH) is transcribed by two genes, while only one codes for the pirroline-5-carboxilate dehydrogenase enzyme (P5CDH) (Ribarits et al., 2007).

The salinity tolerance varies according to the species, growth phase, and the acclimatization characteristic of an individual plant (Akbari et al., 2007). The comprehension of the morphological, physiological, biochemical, and molecular variations induced by salinity in plants help identify the mechanisms involved in the tolerance.

The cultivar BRS AG demonstrates excellent genetic potential for the production of alcohol from cerals and/or animal feed as a new alternative to diversify rice cultivation, providing greater economic sustainability to the sector (Magalhães Júnior et al., 2017). Recent studies show that cv. BRS AG is genetically similar to the Arborio genotype, broadly used in italian cuisine. Cultivar BRS AG also shows higher productivy than Arborio, producing roughly 10.000 $\mathrm{kg} / \mathrm{ha}^{-1}$. Regarding ethanol production, at $0.2 \%$ enzyme concentration BRS Pampa produces $132 \mathrm{gL}^{-1}$ and cV. BRS AG produces $155.1 \mathrm{gL}^{-1}$. Likewise, bromatological analysis showed significant total protein values $51.54 \%$, while cv. BRS Pampa showed 46.45\% (Magalhães Júnior et al., 2017).

Due to the economic relevance and low number of studies, especially regarding the cultivar behavior to abiotic stress, that the goal of this study was to evaluate the germination, morphological characteristics, proline accumulation and the gene expression involved in the metabolism of this aminoacid in rice plants, cV. BRS AG, cultivated in vitro under salt stress In order to know the level of tolerance of this $\mathrm{cv}$. with respect to this stress facilitating the planning of the cultivation of this variety.

\section{Results and discussion}

Germination percentage of cultivar BRS AG under different $\mathrm{NaCl}$ concentrations

The variance analysis and Student'st-test for the germination percentage demonstrated a significant influence $(p \leq 0.05)$ of the salinity levels over the germination vigor of the rice seeds. A comparison of the final germination and first count data showed that the increasing $\mathrm{NaCl}$ concentrations had a moderate effect on the germination during the initial state.

From the results in Table 2 it can be observed that the average germination rate in the first and second evaluation was not affected until the concentration of $136 \mathrm{mM}$. As expected, the salinity of the medium extended the germination time for seeds of $\mathrm{cV}$. BRS AG. The salinity reduces seed germination by decreasing external osmotic potential, preventing water absorption, slowing seed soaking, and rootlet elongation (Soares et al., 2015). If seeds are suffering hydric restriction, their hydration is affected, requiring more time to find an osmotic balance mechanism (Thiam and Champion, 2013). This effect may delay germination since high salinity levels induce to the toxic effects on seeds (Parihar et al., 2015). Toxicity leads to changes in enzymatic activity (Gomes-Filho et al., 2008), in protein metabolism (Meng et al., 2014), hormonal imbalance (Ozhan and Hajibabaei, 2013) and reduction in seed reserves use (Othman et al., 2006).

Similar results were observed for rice genotypes BRS Bojuru, BRS Talento and Cana Roxa, which belongs to Group Japônica; and BRS Atalanta, BRS Firmeza, BRS Pelota, BRS Agrisul, BRS Querência, BRS 7 "Taim" and BRS Ligeirinho belonging to the Indica group, derived to Embrapa Clima Temperado, cultivated in vitro under different $\mathrm{NaCl}$ concentrations (Benitez et al., 2010). For the studied genotypes, the concentrations above $136 \mathrm{mM}$ inhibited germination, Being that the genotype BRS Bojuru is considered tolerant, whereas BRS 7 "Taim" and BRS Ligeirinho are the most sensitive to salinity.

In an in vitro study on rice cultivar Kum DoiSaket, Umnajkitikorn et al., (2016) observed germination delay in seeds subjected to salt stress at $150 \mathrm{mM}$ of $\mathrm{NaCl}$ concentration, and the seed germination was reduced to $17 \%$ and was completely aborted at $300 \mathrm{mM}$. These observations agree with the results shown in this study with BRS AG, where $\mathrm{NaCl}$ concentrations up to $136 \mathrm{mM}$ did not 
Table 1. List of primers used in RT-qPCR and amplicon size reactions. Annealing temperature $61^{\circ} \mathrm{C}$.

\begin{tabular}{|c|c|c|c|}
\hline Gene & $\begin{array}{l}\text { RAP-DB } \\
\text { (Database) }\end{array}$ & $\begin{array}{l}\text { Senso/Antisenso } \\
\text { (Primers) }\end{array}$ & $\begin{array}{l}\text { Amplicon } \\
\text { (pb) }\end{array}$ \\
\hline \multirow[t]{2}{*}{ P5CS1 } & Os05t0455500-01 & 5' AGAGATTGTTCAAGGCATCTACAG 3' & 161 \\
\hline & (AK101985) & 5'AACCAAAGGCTTCTCATATCCAG 3' & \\
\hline \multirow[t]{2}{*}{ P5CS2 } & Os01t0848200-01 & 5' GGTTGATTATCCAGCAGCGT3' & 150 \\
\hline & (AK101230) & 5'CCCGCCATAGATAACTACCC 3' & \\
\hline \multirow[t]{2}{*}{$P 5 C R$} & Os01t0948400-01 & 5' GTTGGTCTGGTCATCGAAGATT3' & 104 \\
\hline & (AK070184) & 5'CATTCTCAGTAGCCATCTCCC 3' & \\
\hline \multirow[t]{2}{*}{$\mathrm{P} 5 \mathrm{CDH}$} & Os05t0536400-01 & 5' AGCAGAGGATGTGGACTTCA 3' & 132 \\
\hline & (AK121765) & 5'GCCTTTCAAATCAGCAGCC 3' & \\
\hline \multirow[t]{2}{*}{$P D H$} & Os10t0550900-01 & 5' GGGTTCCAGGTGAGCAAG 3' & 106 \\
\hline & (AK121010) & 5'AAGGAGGAAGACGAGAGCA 3' & \\
\hline \multirow[t]{2}{*}{$O A T$} & Os03t0643300-01 & 5' TGCTGTGTATCAAACCAGGA 3' & 160 \\
\hline & (AK108010) & 5'CTTTCAACGAGACCTTCATCTG 3' & \\
\hline \multirow[t]{2}{*}{ UBQ10 } & Os02t0161900-01 & 5' TGGTCAGTAATCAGCCAGTTTGG 3' & 105 \\
\hline & (AK101547) & 5'GCACCACAAATACTTGACGAACAG 3' & \\
\hline
\end{tabular}
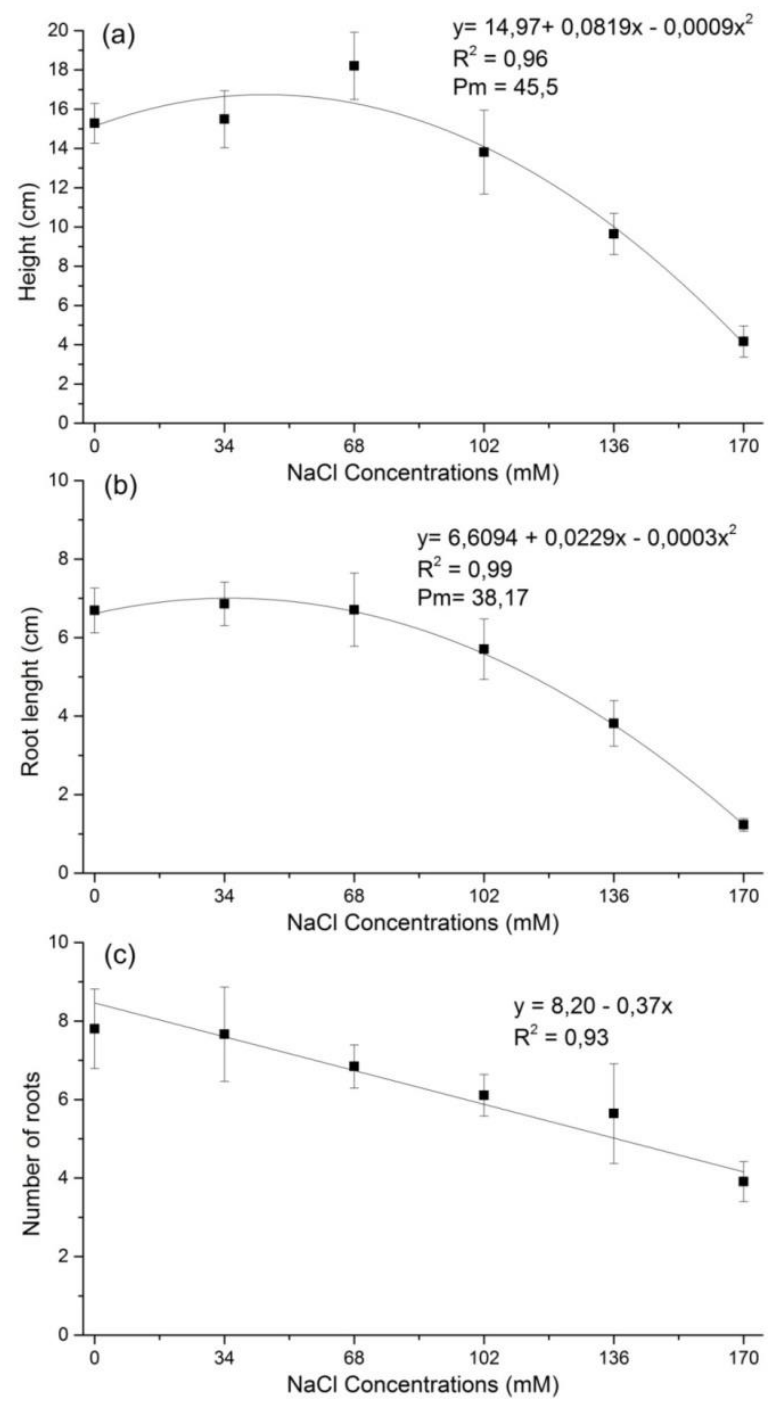

Fig 1. Height (A), root lenght (B) and number of roots (C) of rice plants, cultivar BRS AG, submitted to different concentrations of $\mathrm{NaCl}$ for 21 days. The values are represented by the average of each treatment $\pm D P(n=5)$. Mp = Maximum point. 
Table 2. Percentage of germination of rice, cultivar BRS AG, submitted to different concentrations of $\mathrm{NaCl}$, evaluated at 7 and 14 days.

\begin{tabular}{lcc}
\hline $\mathrm{NaCl}(\mathrm{mM})$ & 1a avaliação (7 dias) & 2a avaliação (14 dias) \\
\hline $0 \mathrm{mM}$ & $93 \pm 0.11 \mathrm{a}$ & $93 \pm 0.11 \mathrm{a}$ \\
$34 \mathrm{mM}$ & $98 \pm 0.04 \mathrm{a}$ & $100 \mathrm{a}$ \\
$68 \mathrm{mM}$ & $89 \pm 0.10 \mathrm{a}$ & $99 \pm 0.07 \mathrm{a}$ \\
$102 \mathrm{mM}$ & $84 \pm 0.07 \mathrm{a}$ & $93 \pm 0.06 \mathrm{a}$ \\
$136 \mathrm{mM}$ & $87 \pm 0.13 \mathrm{a}$ & $93 \pm 0.06 \mathrm{a}$ \\
$170 \mathrm{mM}$ & $62 \pm 0.17 \mathrm{~b}$ & $73 \pm 0.13 \mathrm{~b}$ \\
\hline
\end{tabular}
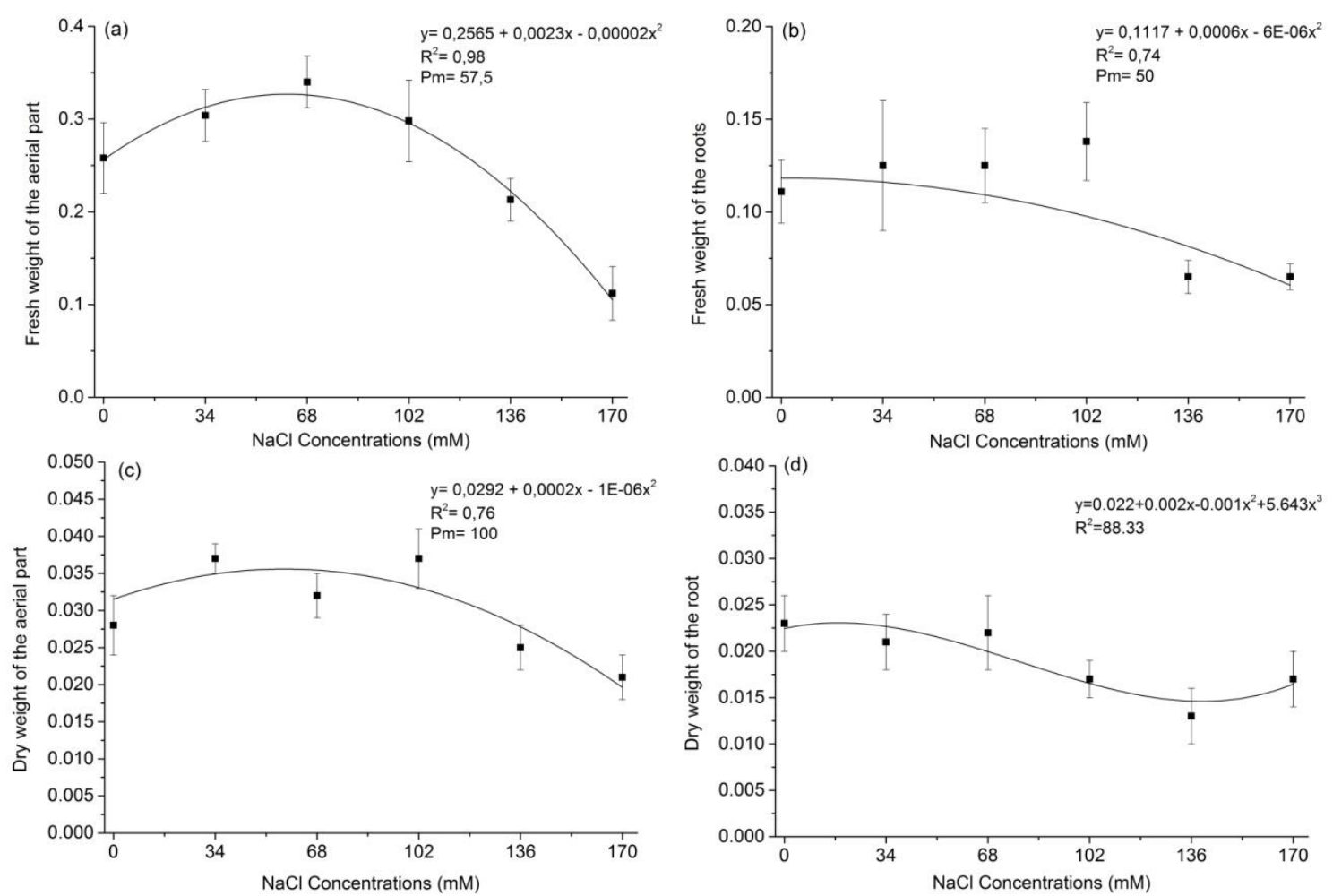

Fig 2. Fresh weight of the aerial part (A), fresh weight of the root (B), dry weight of the aerial part (C) and dry weight of the root (D) of rice plants, cultivar BRS AG, submitted to different concentrations of $\mathrm{NaCl}$ for 21 days. The values are represented by the average of each treatment $\pm D P(n=5)$. Mp = Maximum point.

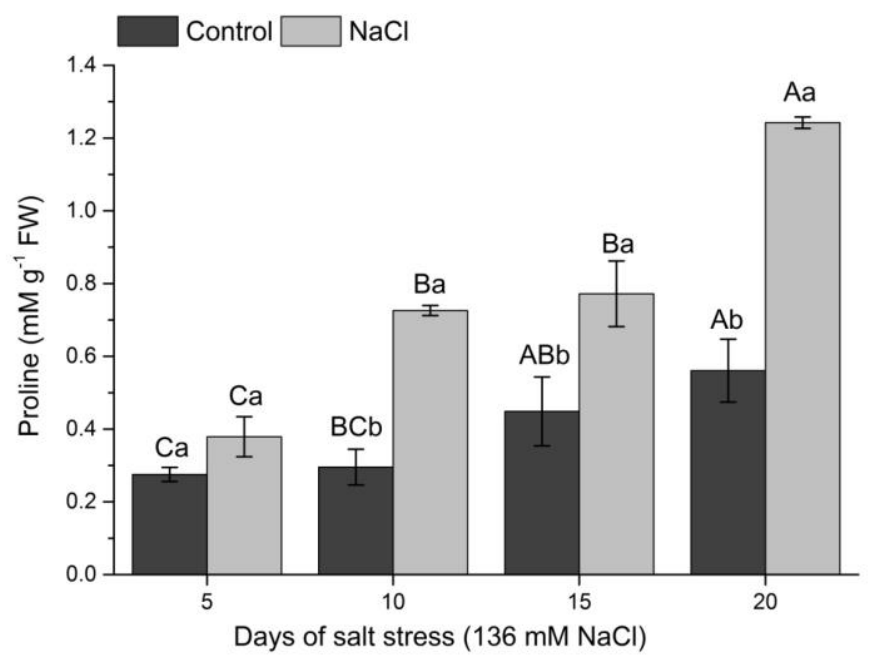

Fig 3. Concentration of free proline present in leaves of rice, cultivar BRS AG, collected at $5,10,15$ and 20 days, both in presence $(136 \mathrm{mM}$ of $\mathrm{NaCl}$ ) and absence (control) of salt. Capital letters indicate significant difference $p \leq 0.05$ between days of stress for the same treatment and lowercase letters indicate differente between $\mathrm{NaCl}$ concentration and the control at each days. Average \pm standard deviation $(n=3)$. 

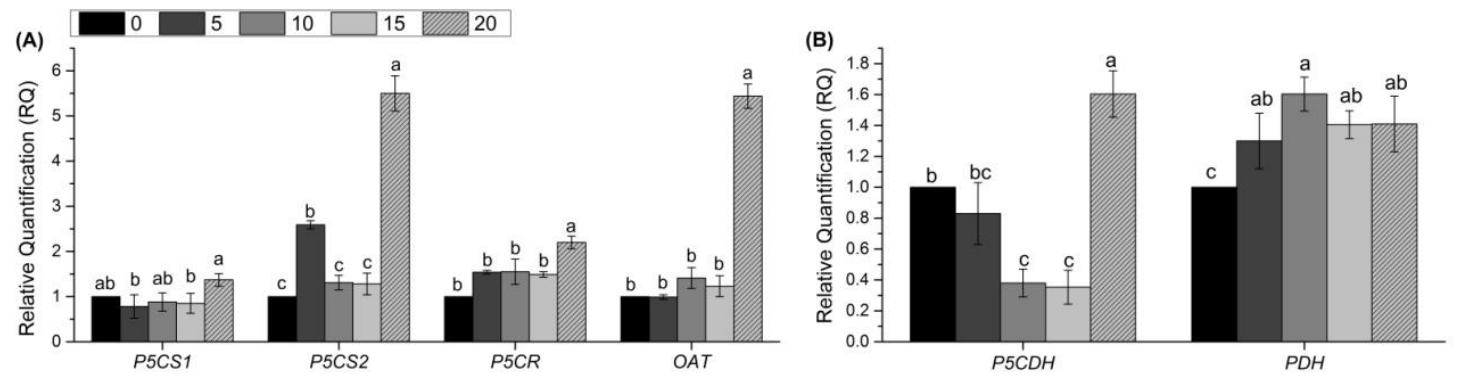

Fig 4. Relative Quantification (QR) of the gene expression of biosynthesis (A) and catabolism (B) of proline in rice plants, cultivar BRS AG, submitted to salinity conditions $(136 \mathrm{mM}$ of $\mathrm{NaCl}$ ) in different times of stress. Time zero represents the control plants that were collected at the same time interval of the others. Lowercase letters indicate significant difference $p \leq 0.05$ between the days of stress. Averages \pm standard deviation $(n=3)$.
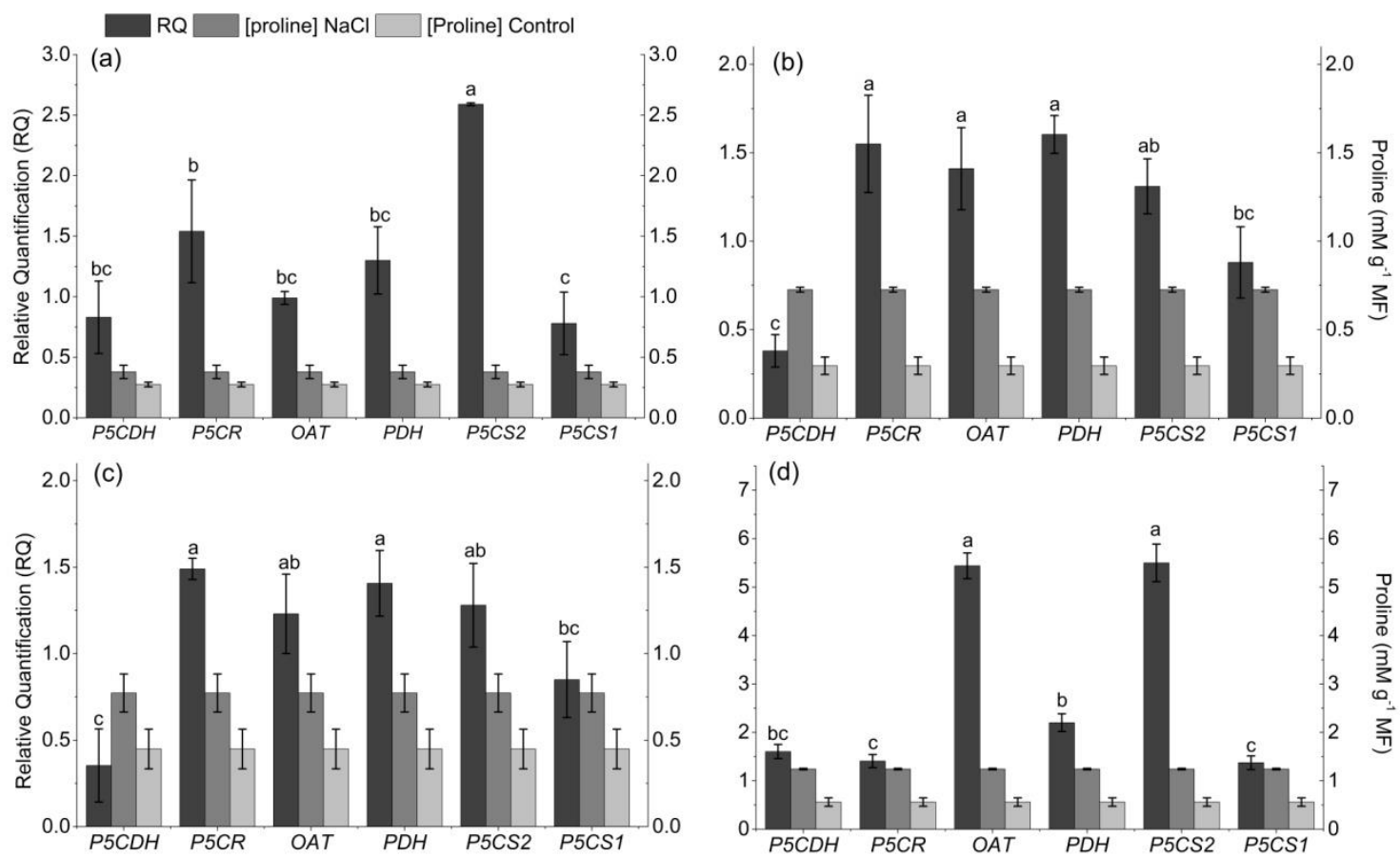

Fig 5. Expression of genes related to proline metabolism in each of the times of stress (days) evaluated compared to the concentration of proline synthesized in rice plants, in salt stress conditions (136 mM of NaCl). Different letters indicate statistical difference for the expression of genes related to proline metabolism. Averages \pm standard deviation $(n=3)$. Five days of salt stress (A), 10 days of salt stress (B), 15 days of salt stress (C) and 20 days of salt stress (D).

affect germination. Therefore, the BRS AG cultivar can be considered salt tolerant in the evaluated conditions, as it germinated at up to $170 \mathrm{mM}$.

\section{Morphological response of BRS AG cultivar to salt stress}

Considering the fact that rice is a sensitive species during initial growth, some morphological characteristics of BRS AG cultivar were evaluated to understand its behavior in stress conditions. The observations made for the plants subjected to salt stress indicated that only the number of leafs variable, by variance analysis, was not affected by the treatments.

The height of the seedlings was affected from the concentration of $68 \mathrm{mM}$, and in this concentration the seedlings already had the reduced root length (Figure $1 \mathrm{~A}$ and B). When the salt concentration in the medium is increased, a decrease in the mean number of roots was also observed (Fig. 1C). These results agree with the data obtained for other rice cultivars exposed to several levels of salt stress (Alamgir and Yousuf, 2006). Rice plants, similarly have had the height was reduced at high concentrations (between 100 and $200 \mathrm{mM}$ ), compared to the control plants (Amirjani, 2010; Wankha et al., 2013). The radicle length in the rice cultivar MTU 1010 was affected by $\mathrm{NaCl}$ at day 21 . An $8 \%, 33 \%$ and $51 \%$ length decrease occurred at 25,50 and $100 \mathrm{mM} \mathrm{NaCl}$ concentrations, respectively. The authors claimed that the growth reduction under salt stress occurred mainly by cellular swelling (Das et al., 2016). Their results agree with those found in the present study, where 21-dayold plants showed marked reductions in aerial part and root system growth at an $\mathrm{NaCl}$ concentration of $100 \mathrm{mM}$ and 
above. According to Orsini et al., (2012), the root growth reduction occurring at high salinity levels can be interpreted as a plant protection mechanism, avoiding the absorption of toxic ions in the aerial part and keeping plant development unimpaired. This behavior can explain the decrease in root growth compared to the aerial part. In contrast to the obtained results, Benitez et al., (2010) showed that growth in the aerial part in ten rice genotypes was more affected by salinity than root system growth, after 21 days of exposure to different $\mathrm{NaCl}$ concentrations. Similarly Balkan et al., (2015) when evaluating the rice cultivar Osmancik-97 in saline conditions observed a reduction in the number of roots. The number of roots significantly increased up to 80 $\mathrm{mM}$ salt concentration and then reduced at higher values of salt. According to Dalton et al., (2000), the reduced formation of new roots in plants subjected to stress by high levels of salinity can be explained as a plant acclimation change. A decrease in the number of roots also decreases the contact area with the medium and the absorption of toxic ions by the plant. From the concentration of $68 \mathrm{mM}$, it was observed a reduction of the free mass of the aerial part (Fig. 2A). In relation to the fresh root mass the highest damages were observed from $102 \mathrm{mM}$ (Fig. 2B). As expected, there was a reduction the dry weight of the aerial part in the highest salt concentrations. With respect to the dry weight of the root, an initial reduction of the dry mass was observed, but it seems that the effect it is not as drastic as observed in other parts of the plant analyzed (Fig. 2C e D). Marked reduction in the fresh weight of the aerial part in rice can be explained by the fact that the rice leaves contain approximately $80 \%$ water, and these alterations are a product, in part, of the decrease in water retention caused by salt stress.

Moreover, it differed from the results obtained for another rice cultivar, Três Rios, which presented a significant decrease in the fresh weight of aerial part and in the root already $100 \mathrm{mM}$ salt concentration (Morales et al., 2012). According to Khare et al., (2015), the reduced biomass in rice under salt stress can be caused by the accumulation and effects of $\mathrm{Na}^{+}$and $\mathrm{Cl}^{-}$, indicates the inability of BRS AG cultivar to limit the ion absorption in its root and leaf tissue at high $\mathrm{NaCl}$.

These results are in agreement with those previously reported by Mekawy et al., (2015), who evaluated the dry weight of the rice cultivars Sakha 102 and Egyptian Yasmine. The dry weight of both the cultivars was affected by salt stress $(50 \mathrm{mM}$ of $\mathrm{NaCl}$ ), which was more drastic for the cultivar Sakha 102. According to Parihar et al., (2015), the cause of this injury is an elevated salt absorption, which surpasses the plant's vesicle storage capacity. Hence, the increased salt concentration in the cytoplasm, especially $\mathrm{Na}+$, inhibits and changes the activity of enzymes in several metabolic pathways, as well as protein structure function. Alternatively, these salts can accumulate in the cell wall and dehydrate the cell, which might be an underlying cause of the reduction fresh weight in $\mathrm{BRS}$ AG cultivar at high $\mathrm{NaCl}$ concentrations.

\section{Concentration of free proline}

The results of the variance analysis showed a significant effect of salinity on the concentration of free proline. $\mathrm{NaCl}$ at $136 \mathrm{mM}$ concentration caused an increase in the proline content during the whole period of stress, comparing with control plants. While evaluating $\mathrm{NaCl}$ concentrations, it was observed that after five days of germination, the plants with $(136 \mathrm{mM})$ and without stress $(0 \mathrm{mM})$ had no statistically significant difference, while after 10-20 days of growth, the $136 \mathrm{mM} \mathrm{NaCl}$ concentration showed prominent effect on the proline content compared to the control (Fig. 3). While analyzing the effect of a particular salt concentration at different days of growth, it was noted that the plants attained their highest value proline content $\left(1.24 \mathrm{mM} \mathrm{g}^{-1}\right.$ MF) 20 days after the growth in a saline medium. This proline concentration was significantly higher when compared to the days 5, 10 and 15 , respectively.

One of the plant responses to salt stress at the cellular level includes the synthesis and accumulation of some osmoprotectants, known as compatible solutes (Silveira et al., 2010). Proline is an amino acid that is increased in plants under stress (Joseph et al., 2015). However, besides acting as an osmoprotectant, this amino acid performs other functions in plants under normal and stressed conditions. During an osmotic adjustment, proline prevents the loss of water by the cell. This mechanism allows for the reduction in the osmotic potential and increases the turgescence potential of the cell, thus easing water absorption and cell growth maintenance. According to Silveira et al., (2010), when a mechanism of osmotic adjustment is initiated, the energy demand increases in plants, resulting in slow growth, as observed in cv. BRS AG, evaluated in the present study.

In the $\mathrm{CV}$. BRS AG, the proline concentration was always higher in stressed plants at all the days of evaluation, and increased with a longer stress exposure. As a protective agent during stress, proline can perform several functions such as prevent protein denaturation, stabilize the quaternary structure and membrane destabilization, and act as a chemical chaperon (Yancy et al., 1982). It can also act as a non-enzymatic antioxidant, inhibiting the formation or decreasing the damage caused by ROS, in energy storage and transference, and as a reducing agent (Szabados and Savouré, 2010). Similar results were observed by Das et al., (2016) in roots and leaves of rice cultivar MTU 1010. The plants, evaluated at day 21 of age, showed an increase in proline concentration when exposed to $\mathrm{NaCl}$ treatments (25, 50 and $100 \mathrm{mM}$ ). The proline values were higher in the aerial parts than in the roots at $100 \mathrm{mM} \mathrm{NaCl}$ concentration.

These results are expected since in previous studies with seven rice cultivars subjected to different levels of salt stress, varying from 0 to $200 \mathrm{mM}$ of $\mathrm{NaCl}$, it was observed that all cultivars showed an increase in proline concentration with the increase in salt concentration (Joseph et al., 2015). Foliar application of proline resulted in a significant increase in growth and other parameters evaluated in rice (Siddique et al., 2014). In response to the proline application, there was an increase in nutrient absorption and antioxidant defense in these plants (Hasan et al., 2015).

\section{Expression of genes related to the proline metabolism}

In this work, the rice plants grown in vitro at saline medium always showed higher proline concentration and a progressive concentration increase during the course of time and stress exposure. To justify this increase in proline, the genes involved in the metabolism of this amino acid were evaluated. As shown in Fig. 4A, the expression of P5CS1 and 
P5CS2 genes, responsible for the synthesis of the pyrroline5-carboxylate synthetase (P5CS) enzyme, which catalyzes the first step of the proline biosynthesis, was induced by salt stress during the whole course of exposure. The highest expression levels of genes P5CS1 and P5CS2, in the evaluated tissues, were attained at day 20 of the stress with $Q R$ values $=1.37$ and 5.50, respectively, and only the P5CS1 gene did not differ from the expression levels found in the control plants and at day 10 of the stress. The P5CS2 gene response in the plants at days 10 and 15 of the stress did not differ from the control.

Through the plant the duration of exposure to the salt stress, it was verified that mRNA levels of OAT gene were significantly higher in tissues the day 20 of the exposure, with $Q R=5.44$. Likewise, the highest expression of the P5CR gene, which codes for the enzyme converting pyrroline-5carboxylate into proline, occurred at the highest stress exposure time with $Q R=2.20$.

Regarding the represented expression of catabolism genes (Fig. 4B), it can be observed that $P 5 C D H$ gene, which codes for an enzyme that converts $P C 5$ to glutamate, showed maximum expression at day 20 of the stress, which was significantly higher than other evaluated days, but differed from the expression behavior of the $P D H$ gene, which had already showed maximum expression at day $10(Q R=1.40)$, compared to the control sample.

Based on the results of gene expression throughout several days of salt stress, it was deduced that the elevated levels of proline in stressed plants are due to the higher expression of genes involved in the proline biosynthesis, when compared with genes that code for catabolism enzymes. Likewise, high expression levels of the P5CS2 and OAT genes, at day 20 of the stress, are in line with the high concentrations of proline in this period.

It proposed that proline biosynthesis by glutamate and ornithine prevails in normal and stressed conditions in young plants of Arabidopsis. However, it was stated that the ornithine pathway plays a fundamental role only in adult plants suffering from osmotic stress. Some authors claim that the ornithine pathway operated during ideal nitrogen conditions and vegetative growth (Armengaud et al., 2004). The elevated levels of proline via ornithine were observed in this study in the rice cultivar BRS AG.

Several studies have shown that P5CS transcription in plants, although varies according to the species, is promoted mainly by adverse environmental conditions like drought, salinity, and high and low temperatures. These studies also show that P5CS1 gene expression prevails in salt stress situations (Székely et al., 2008). The BRS AG cultivar also showed increased expression of the gene P5CS1, although at lower levels compared to P5CS2. Similar results were found in rice by Hur et al., (2004). According to these authors, both P5CS1/P5CS2 responded in the plants grown under stress. The authors concluded that the P5CS1 gene is involved in maintenance, providing abasal level of proline to the cell, while P5CS2 is the first to respond to stressed conditions.

During proline biosynthesis, pyrroline-5-carboxylate (P5C), when accumulated in excess, can cause reactive oxygen species (ROS) production and induce apoptosis causing cell death (Székely et al., 2008). Therefore, plants need to degrade it rapidly, as soon as the tension is relieved. Proline catabolism occurs in the mitochondria through the action of proline dehydrogenase (PDH) or proline oxidase (POX) producing $\mathrm{P} 5 \mathrm{C}$, which is converted to glutamate through $\mathrm{P} 5 \mathrm{C}$ dehydrogenase (P5CDH) (Szabados and Savouré, 2010).

\section{Relation between expression of proline metabolism genes} and its concentration in evaluated tissues

A relation between the expression level of genes involved in the proline metabolism and the proline concentration was sought during the whole evaluation period. As shown in Fig. $5 \mathrm{~A}$, five days after the germination, the proline concentration in the stressed plants was found to be higher due to a significant increase in the P5CS2 and P5CR gene expressions.

The results shown in Fig. $5 B$ indicate that, at day 10 of the stress, the expression of genes $P 5 C R(Q R=1.55), O A T(Q R=$ $1.41)$, and $P D H(Q R=1.60)$ was superior to the others, not differing only from P5CS2 gene. This shows that the elevated expression of $P D H$, which codes for one of the proline degradation enzymes, had no effect in the reduction of proline concentration in stressed plants at day 10 . This can be explained by the low expression of the gene coding for $P 5 C D H$, an enzyme involved in the final catabolic pathway, which prevents degradation of the amino acid during stress. The gene expression behavior was similar to that at day 15 , due to no significant difference in the proline concentration at day 10 (0.726 mM proline $\left.\mathrm{g}^{-1} \mathrm{MF}\right)$ and day 15 (0.772 mM proline $\mathrm{g}^{-1} \mathrm{MF}$ ) (Fig. $5 \mathrm{C}$ ).

At day 20 of the stress (Fig. 5D), while comparing the gene expression, the data showed that the increased expression of P5CS2, OAT and, to a lesser extent, P5CR genes, which code for the enzymes involved in proline biosynthesis and, consequently, the low expression of genes regulating degradation enzymes, contributed to the increase in proline concentration in rice plants of cultivar BRS AG.

As shown in Fig. 5A, the P5CS1 expression was not very responsive in this day. The high mRNA levels for P5CS2 may have contributed to the low expression of P5CS1. Indirect regulation by the light can also be attributed as a cause. The cultivar used in this study was kept in the dark during the first five days of germination and transferred in light after this period. In a study made with Arabidopsis, the authors proposed that light can have an indirect effect on the regulation of P5CS1 expression, but the light has a negative effect on PDH expression. Light activates P5CS1 expression because, under these conditions, with increased photosynthesis, osmotic potential decreases and proline demand in the cell increases. Although in stress situations, P5CS1 expression in the dark was observed, while $P D H$ was unresponsive in both conditions (Hayashi et al., 2000). Ábrahám et al., (2003) verified that proline synthesis stimulation by abscisic acid (ABA) $(10 \mu \mathrm{M})$ and salt stress (200 mM) correlated with the activation of P5CS1 expression. Conversely, P5CS2 is weakly induced, while $P D H$ is inhibited in different proportions by $A B A$ and salt stress in the aerial part and the roots of plants grown in light. P5CS1 expression, signaled by $A B A$ and salt stress, is practically inhibited in the plants kept in the dark, reducing accumulated proline concentration.

In this study, it was observed that the high expression levels of $P D H$ gene did not cause a reduction in proline concentration in plants evaluated at day 10 and 15 of stress, which can probably be attributed to the return of $\mathrm{P} 5 \mathrm{C}$ to the cytosol, converting into proline again. Conversely, $\mathrm{P} 5 \mathrm{CDH}$ 
expression was low comparing to other genes, hence the enzyme that oxidizes P5C to glutamate was not activated, and proline could not be completely degraded. Likewise, the observation that $P D H$ gene responded to stress does not mean proline dehydrogenase was also activated. Silva Ortega et al., (2008) observed in studies with cactus that while the gene transcription was increased, enzymatic activity was not. At day 20 of the stress, the significantly higher expression of genes P5CS2 and OAT resulted in increased levels of proline concentration. P5CS2 gene expression has been attributed by many authors to protect the plant from Reactive Oxygen Species (ROS) (Fabro et al., 2004).

Proline biosynthesis requires NADPH for glutamate reduction to pyroline-5-carboxilate $(\mathrm{P} 5 \mathrm{C})$ and then to proline, producing $\mathrm{NADP}^{+}$, which can be used as an electron receptor. Glutamate phosphorylation uses ATP and produces ADP, which is a substrate for ATP biosynthesis during photosynthesis. An increased rate of proline biosynthesis during stress can keep the NADPH: NADP ${ }^{+}$ relation at low levels, contributing to the preservation of the electron flow between the photosynthetic reaction center, stabilizing redox balance, reducing photoinhibition, and damage to the photosynthetic machinery.

In mitochondria, proline protects the complex II of the electron transport chain during salt stress (Hamilton and Heckathorn, 2001). When no longer in stress, proline is degraded in the mitochondria by PDH and P5CDH enzymes, which provides electrons to the transport chain by oxidizing proline, causing the plant to resume growth. Hence, proline catabolism plays an important role in reactive oxygen species (ROS) balance in the cell (Hayat et al., 2012). As an alternative to ROS removal, proline can function in the protection and stabilization of cellular detoxification enzymes.

\section{Materials and methods}

\section{Plant material}

The experiment was conducted in the Plant and Tissue Culture Laboratory, a part of the Botanic Department, Biology Institute of the Universidade Federal de Pelotas (UFPel), located in the city of Capão do Leão, Rio Grande do Sul. Only seeds from rice cultivar BRS AG from Estação Experimental Terras Baixas (Embrapa - Clima Temperado) were used.

\section{Plant cultivation conditions}

Before germination, the seeds were manually dehusked and disinfected with $70 \%$ alcohol for $2 \mathrm{~min}$ and in a $3 \%$ sodium hypochlorite solution for $25 \mathrm{~min}$, followed by three washings with autoclaved distilled water. All steps were carried out under light and constant agitation in a laminar flow chamber. After the last washing, the seeds were dried on a sterile filter paper and germinated in test tubes containing $15 \mathrm{~mL}$ of MS medium (Murashige and Skoog, 1962) with half of the original salt concentration, supplemented with different concentrations of $\mathrm{NaCl}, 10 \mathrm{gL}^{-1}$ of sucrose, 100 $\mathrm{mgL}^{-1}$ of myoinositol and $7 \mathrm{gL}^{-1}$ of agar as solidifying agent at $\mathrm{pH}$ adjusted to 5.8. The test tubes were closed with aluminum foil and autoclaved at 121 ㅇ C for $20 \mathrm{~min}$. The crop was kept in a BOD incubator at $28{ }^{\circ} \mathrm{C}$ with no light for five days. After this, the seedlings were transferred to a growth room, with a photoperiod of $16 \mathrm{~h}$, where they were kept until day 21. In order to determine the concentration of proline, the plant samples were collected at days 5, 10, 15, and 20 of the stress, and stored at -70 oc for further analysis.

\section{Experimental design}

The experiment was conducted in a completely randomized design, the treatments consisting of a control group with no $\mathrm{NaCl}$ addition, and five others, each representing an $\mathrm{NaCl}$ concentration of $34,68,102,136$ and $170 \mathrm{mM}$.

Three repetitions were employed in the evaluation of germination, with each repetition considering 15 plants. The values related to the germination percentage were transformed to an arcsine square root of $X / 100$, where $X$ represents the percentage value obtained as the "\% of plants emerged" variable. The peak was also determined using the formula $-b / 2 c$. The morphological characterization consisted of five repetitions, each being represented by three tubes containing a seedling each, with a total of 15 plants per treatment. To determine the proline levels, an $\mathrm{NaCl}$ concentration of $136 \mathrm{mM}$ and a control (without $\mathrm{NaCl}$ ) were used in three repetitions, each consisting of 15 plants. On the basis of the morphological characteristics, it was observed that, at an $\mathrm{NaCl}$ concentration of $136 \mathrm{mM}$ and above, the plants exhibited growth damage. Therefore, this concentration was chosen for the determination of proline levels and other analyses.

The data were then subjected to an analysis of variance to test the variation sources (Tissue $\mathrm{x} \mathrm{NaCl}$ concentration) and its possible interactions. Results with $\mathrm{P} \leq 0.05$ were considered relevant, and the mean values were compared by Tukey test $(5 \%)$. The regression analysis was done with the software SAS v.9.3 (SAS Institute Inc., Cary, NC).

\section{Evaluation of the germination percentage and morphological characteristics}

The germination was counted twice: at days 7 and 14 of the seeding. Radicle protrusion was the standard used to classify the germinated seeds. For the evaluation of the morphological characteristics, the plants were collected at day 21 , and their height $(\mathrm{cm})$, root length $(\mathrm{cm})$, leaf number, fresh weight of the shoot and root system (g) were evaluated. Dry weight of the shoot and root system was

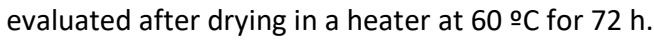

\section{Determination of proline concentration}

The extraction and determination of proline were carried out following the methodology developed by Bates et al., (1973), with a few adaptations. Approximately $500 \mathrm{mg}$ of leaf and seed fresh mass was macerated in liquid nitrogen, homogenized in $2 \mathrm{~mL}$ of a $3 \%$ sulfosalicylic aqueous solution $(\mathrm{p} / \mathrm{v})$, centrifuged at $1000 \mathrm{~g}$ for $20 \mathrm{~min}$, and the supernatant was collected. The obtained supernatants were transferred to threaded vials, where $2 \mathrm{~mL}$ of glacial acetic acid and $2 \mathrm{~mL}$ of ninhydrin were added, the tubes being kept at $100 \stackrel{\circ}{ } \mathrm{C}$ water bath for $60 \mathrm{~min}$. The samples were then kept in ice and dark for $10 \mathrm{~min}$. After cooling in an ice bath, $4 \mathrm{~mL}$ of 
toluene was added, and the samples were agitated. When two phases were formed, $1 \mathrm{~mL}$ of the upper phase (pink) was collected, which was then analyzed by a spectrophotometer at $520 \mathrm{~nm}$. The sample was not added to the control (white), and all other procedures were the same. The obtained absorbance was compared to the proline standard curve, and the results were expressed in $\mathrm{mM}$ proline $\mathrm{g}^{-1} \mathrm{FM}$ (fresh mass).

\section{Expression (RT-qPCR) analysis of proline-related genes}

Each macerated plant sample (100 mg) was transferred to a $1.5 \mathrm{~mL}$ nuclease-free microtube, with PureLink ${ }^{\circledR}$ Kit (Invitrogen ${ }^{\mathrm{TM}}$ ) extraction buffer added immediately after. The total RNA content and purity were determined using a spectrophotometer by taking absorbance at 260 and 280 $\mathrm{nm}$. The nucleic acid integrity was evaluated by $1.5 \%$ agarose gel electrophoresis.

The samples were treated with DNAse I, using the amplification grade DNAse I Kit (Sigma-Aldrich ${ }^{\circledR}$ ) for the removal of possible genomic DNA residues, following the manufacturer's instructions. The total RNA samples treated with DNAse I were subjected to reverse transcription PCR for the complementary DNA synthesis. For each sample, singlestranded cDNA was made from RNA $(1 \mu \mathrm{g} / \mu \mathrm{L})$, using the Super Script First Strand System for RT-PCR (Invitrogen) kit. The RT-qPCR analyses were conducted in a Bio-Rad CFX RealTime thermocycler, using the SYBR Green (Roche ${ }^{\circledR}$ ) fluorophore system. Primers with specific amplicons (with a single dissociation peak of the PCR product) and with a near $100 \%$ ( $E \cong 1.8-2.2)$ amplification efficiency were used. The primers for the genes used are listed in Table 1. The total reaction volume was $12 \mu \mathrm{L}$, which included $6.25 \mu \mathrm{L}$ of the fluorophore, $0.25 \mu \mathrm{L}(10 \mathrm{mM})$ of each primer (sense and antisense), $1 \mu \mathrm{L}$ of cDNA (1:5 previously defined dilution), and $4.25 \mu \mathrm{L}$ of ultrapure water. The amplification conditions were as follow: $95{ }^{\circ} \mathrm{C}$ for $10 \mathrm{~min}, 40$ cycles at $95^{\circ} \mathrm{C}$ for $15 \mathrm{~s}$, $60^{\circ} \mathrm{C}$ for $1 \mathrm{~min}$ with the insertion of melting curve at 65 to $95{ }^{\circ} \mathrm{C}$, incrementing $5{ }^{\circ} \mathrm{C}$ at each fluorescence measure. The OsUBQ10 gene was used as internal control (Moraes et al. 2015). The relative quantification of differential expression was made using the $\mathrm{CT}$ (comparative threshold cycle method) method, as described by (Livak and Schmittgen, 2001).

\section{Conclusion}

Based on the results obtained in this study, it can be concluded that (i) the seed germination of BRS AG cultivar starts to be affected at $170 \mathrm{mM} \mathrm{NaCl}$ concentration; (ii) after $136 \mathrm{mM} \mathrm{NaCl}$ concentration, it is possible to observe growth damage caused by salt stress; (iii) increased concentrations of $\mathrm{NaCl}$ reduces growth, the number of roots, root length, aerial part and root fresh weight as well as dry mass production (MSPA and MSR), except for leaf numbers, which was not affected; (iv) root system growth is more affected by salinity than aerial part growth; (v) proline accumulation is greater in stressed plants than in control samples, which is directly related to increased expression of genes involved in proline biosynthesis in each of the measured stress times; (vi) high expression values detected in P5CS2 and OAT genes at day 20 of stress explains the elevated proline concentration in this period; (vii) both the pathways, ornithine and glutamate, contribute to proline accumulation induced by salt stress in cultivar BRS AG; (viii) proline biosynthesis occurs, via cytosol in cV BRS AG, preferentially in salt stress conditions; (ix) according to the in vitro results obtained, the rice cultivar BRS AG can be considered tolerant to salt stress.

\section{Acknowledgments}

This study was supported by the Brazilian research funding agencies: Coordenação de Aperfeiçoamento de Pessoal de Nível Superior (CAPES), Conselho Nacional de Desenvolvimento Científico e Tecnológico (CNPq) and Fundação de Amparo à Pesquisa do Rio Grande do Sul (FAPERGS).

Author contributions Conceived and designed the experiments A.M.M.J, L.B.D., E.J.B.B and L.S.P. Wrote, edited, and analyzed the data: T.R, M.A.C.M, M.N.A, and P.A.A Revised the paper: A.M.M.J, E.J.B.B, R.W and L.S.P. Conducted the experiments: T.R, M.N.A, P.A.A, R.W, and M.A.C.M. All authors readed the paper and approved the final manuscript.

\section{Reference}

Ábrahám E, Rigó G, Székely G, Nagy R, Koncz C, Szabados L (2003) Light-dependent induction of proline biosynthesis by abscisic acid and salt stress is inhibited by brassinosteroid in Arabidopsis. Plant Mol Biol. 51:363372.

Akbari GS, Mohammad A, Yousefzadeh S (2007) Effect of auxin and salt stress $(\mathrm{NaCl})$ on seed germination of wheat cultivars (Triticum aestivum L.). Pak J Biol Sci. 10:25572561

Alamgir ANM, Yousuf Ali M (2006) Effects of $\mathrm{NaCl}$ salinity on leaf characters and physiological growth attributes of different genotypes of rice (Oryza sativa L.). Bangladesh J Bot. 35:99-107.

Amirjani MR (2010) Effect of $\mathrm{NaCl}$ on Some Physiological Parameters of Rice. Ejbs. 3:6-16

Armengaud P, Thiery L, Buhot N, Grenier-De March G, Savouré A. (2004) Transcriptional regulation of proline biosynthesis in Medicago truncatula reveals developmental and environmental specific features. Physiol Plant. 120:442-450.

Asci O (2013) Salt tolerance in red clover (Trifolium pratense L.) seedlings. Afr j biotechnol. 10:8774-8781.

Balkan A, Gençtan T, Bilgin O, Ulukan H (2015) Response of rice (Oryza sativa $\mathrm{L}$.) to salinity stress at germination and early seedling stages. Pak J Agri Sci. 52(2):453-459.

Bates LS, Waldren RP, Teare ID (1973) Rapid determination of free proline for water-stress studies. Plant Soil 39:205207.

Ben Rejeb K, Abdelly C, Savouré A (2014) How reactive oxygen species and proline face stress together. Plant Physiol Biochem. 80:278-284.

Benitez LC, Peters JA, Bacarin MA, et al (2010) Tolerância à salinidade avaliada em genótipos de arroz cultivados in vitro. Rev Ceres. 57:330-337.

Carmona FC, Anghinoni I, Weber EJ (2011) Salinidade da água e do solo e seus efeitos sobre o arroz irrigado no Rio Grande do Sul. IRGA Instituto Rio Grandense do Arroz 
Estação Experimental do Arroz divisão de pesquisa. Boletim Técnico no 10 Cachoeirinha.

Dalton FN, Maggio A, Piccinni G (2000) Simulation of shoot chloride accumulation: separation of physical and biochemical processes governing plant salt tolerance. Plant Soil. 219:1-11

Das P, Seal P, Biswas AK (2016) Regulation of Growth, Antioxidants and Sugar Metabolism in Rice (Oryza sativa L.) Seedlings by $\mathrm{NaCl}$ and Its Reversal by Silicon. Am J Plant Sci. 7:623-638

Fabro G, Kovács I, Pavet V, Szabados L, Alvarez ME (2004) Proline accumulation and At P5CS2 gene activation are induced by plant-pathogen incompatible interactions in Arabidopsis. Mol Plant Microbe Interact. 17:343-50.

Gomes-Filho E, Lima CR, Costa JH, da Silva AC, da Guia Silva Lima M, de Lacerda CF, Prisco JT (2008) Cowpea ribonuclease: Properties and effect of $\mathrm{NaCl}$-salinity on its activation during seed germination and seedling establishment. Plant Cell Rep. 27:147-157.

Hamilton EW, Heckathorn SA (2001) Mitochondrial adaptations to $\mathrm{NaCl}$. Complex $\mathrm{I}$ is protected by antioxidants and small heat shock proteins, whereas complex II is protected by proline and betaine. Plant Physiol. 126(3):1266-74.

Hasan MI, Kibria MG, Jahiruddin M, Murata T, Hoque MAA (2015) Improvement of Salt Tolerance in Maize by Exogenous Application of Proline. Journal of Environmental Science and Natural Resources. 8:13-18.

Hayashi F, Ichino T, Osanai M, Wada K (2000) Oscillation and regulation of proline content by $\mathrm{P} 5 \mathrm{CS}$ and ProDH gene expressions in the light/dark cycles in Arabidopsis thaliana L. Plant Cell Physiol. 41(10):1096-101.

Hayat S, Hayat Q, Alyemeni MN, Wani AS, Pichtel J, Ahmad A (2012) Role of proline

under changing environments: a review. Plant Signal Behav. 7(11):1456-66.

Hur J, Jung $\mathrm{KH}$, Lee $\mathrm{CH}$, An $\mathrm{G}$ (2004) Stress-inducible OsP5CS2 gene is essential for salt and cold tolerance in rice. Plant Sci. 167:417-426.

Joseph E, Radhakrishnan V, Mohanan K (2015) A Study on the Accumulation of Proline - An Osmoprotectant Amino Acid under Salt Stress in Some Native Rice Cultivars of North Kerala, India. Universal J Agric Res. 3(1):15-22.

Kavi Kishor PB, Sangam S, Amrutha RN (2005) Regulation of proline biosynthesis, degradation, uptake and transport in higher plants: Its implications in plant growth and abiotic stress tolerance. Curr Sci. 88(3):424-438.

Khare T, Kumar V, Kishor PBK (2015) $\mathrm{Na}^{+}$and $\mathrm{Cl}^{-}$ions show additive effects under $\mathrm{NaCl}$ stress on induction of oxidative stress and the responsive antioxidative defense in rice. Protoplasma. 252:1149-1165.

Livak KJ, Schmittgen TD (2001) Analysis of relative gene expression data using real-time quantitative PCR. Methods. 25(4):402-408.

Magalhães Júnior A M, Fagundes PRR, Franco DF, Morais OP, Siqueira FG, Streck EA, Aguiar GA, Facchinello PHK. (2017) BRS AG: first cultivar of irrigated rice used for alcohol production or animal feed. Crop Breed Appl Biotechnol. 17: 72-77.

Mekawy AM, Assaha DV, Yahagi H, Tada Y, Ueda A, Saneoka H (2015) Growth, physiological adaptation, and gene expression analysis of two Egyptian rice cultivars under salt stress. Plant Physiol Biochem. 87:17-25.
Meng LB, Chen YB, Lu TC, et al (2014) A systematic proteomic analysis of $\mathrm{NaCl}$-stressed germinating maize seeds. Mol Biol Rep. 41:3431-3443.

Moraes GP, Benitez LC, do Amaral MN, et al (2015) Evaluation of reference genes for RT-qPCR studies in the leaves of rice seedlings under salt stress. Genet Mol Res. 14:2384-2398.

Morales SG, Trejo-téllez LI, Merino FCG, Caldana C, Espinosa-victoria D, Cabrera BEH (2012) Growth, photosynthetic activity, and potassium and sodiumconcentration in rice plants under salt stress. Acta Sci Agron. 34(3):317-324.

Munns R, Tester M (2008) Mechanisms of salinity tolerance. Annu Rev Plant Biol. 59:651-81.

Murashige T, Skoog FA (1962) Revised medium for rapid growth and bioessays with tobacco tissue culture. Physiol Plant. 15:473-497

Orsini F, Alnayef M, Bona S, Maggio A, Gianquinto G (2012) Low stomatal density and reduced transpiration facilitate strawberry adaptation to salinity. Environ Exp Bot. 81:110

Othman Y, Al-Karaki G, Al-Tawaha AR, Al-Horani A (2006) Variation in Germination and Ion Uptake in Barley Genotypes under Salinity Conditions. World J Agric Sci. 2:11-15

Ozhan N, Hajibabaei M (2013) Studies on effectiveness of plant phytohormones in reduction of salinity effects on germination of some cultivar of spring wheat. Int. J. Adv. Biol. Biom. 2 (12):2860-28664.

Parihar P, Singh S, Singh R, Pratap Singh V, Mohan Prasad S (2015) Effect of salinity stress on plants and its tolerance strategies: a review. Environ Sci Pollut Res. 22:4056-4075.

Ribarits A, Abdullaev A, Tashpulatov A, Richter A, Heberlebors E, Touraev A (2007) Two tobacco proline dehydrogenases are differentially regulated and play a role in early plant development. Planta 225:1313-24.

Santos Júnior SRG (2015) Arroz em casca natural. In: conab (ed) CONAB - Companhia Nacional de Abastecimento, vol.(2), Brazilia.

Siddique AB, Ara I, Islam SMS, Tuteja N (2014) Effect of air desiccation and salt stress factors on in vitro regeneration of rice (Oryza sativa L.). Plant Signal Behav 9:977-209.

Silva-Ortega CO, Ochoa-Alfaro AE, Reyes-Agüero JA, AguadoSantacruz GA, Jiménez-Bremont JF (2008) Salt stress increases the expression of P5CS gene and induces proline accumulation in cactus pear. Plant Physiol Biochem. 46(1):82-92.

Silveira JAG, Silva SLF, Silva EN, Viégas RA (2010) Mecanismos biomoleculares envolvidos com a resistência ao estresse salino em plantas. In: GHEYI, H. R.; DIAS, N. S.; LACERDA, C. F. Manejo da salinidade na agricultura. Fortaleza, INCT Sal, p. 472.

Soares MM, Santos Júnior HC, Simões MG, Pazin D, Silva LJ (2015) Estresse hídrico e salino em sementes de soja classificadas em diferentes tamanhos. Pesq Agropec Trop. 45:370-378.

Sociedade Sul-Brasileira de Arroz Irrigado (SOSBAI) (2014) Arroz irrigado: Recomendações Técnicas da Pesquisa para o Sul do Brasil. Editora Pallotti, Bento Gonçalves.

Szabados L, Savouré A (2010) Proline: a multifunctional amino acid. Trends Plant Sci 15(2):89-97.

Székely G, Abrahám E, Cséplo A, Rigó G, Zsigmond L, Csiszár J, Ayaydin F, Strizhov N, Jásik J, Schmelzer E, Koncz 
C, Szabados L (2008) Duplicated P5CS genes of Arabidopsis play distinct roles in stress regulation and developmental control of proline biosynthesis. Plant J. 53(1):11-28.

Thiam M, Champion A, Diouf D, Oureye M (2013) $\mathrm{NaCl}$ effects on in vitro germination and growth of some senegalese cowpea (Vigna unguiculata (L.) Walp.) cultivars. ISRN biotechnol. 11 pages

Umnajkitikorn K, Faiyue B (2016) Enhancing Antioxidant Properties of Germinated Thai rice (Oryza sativa L.) cv. Kum Doi Saket with Salinity. Rice Res Open Access. 4:1-8.
Verbruggen N, Hermans C (2008) Proline accumulation in plants: A review. Amino Acids. 35:753-759.

Wankhade SD, Cornejo MJ, Mateu-Andrés I, Sanz A (2013) Morpho-physiological variations in response to $\mathrm{NaCl}$ stress during vegetative and reproductive development of rice. Acta Physiol Plant. 35:323-333.

Yancy PH, Clark ME, Hand SC, Bowlus RD, Somero GN (1982) Living with water stress: evolution of osmolyte systems. Science. 217:1214-1223 